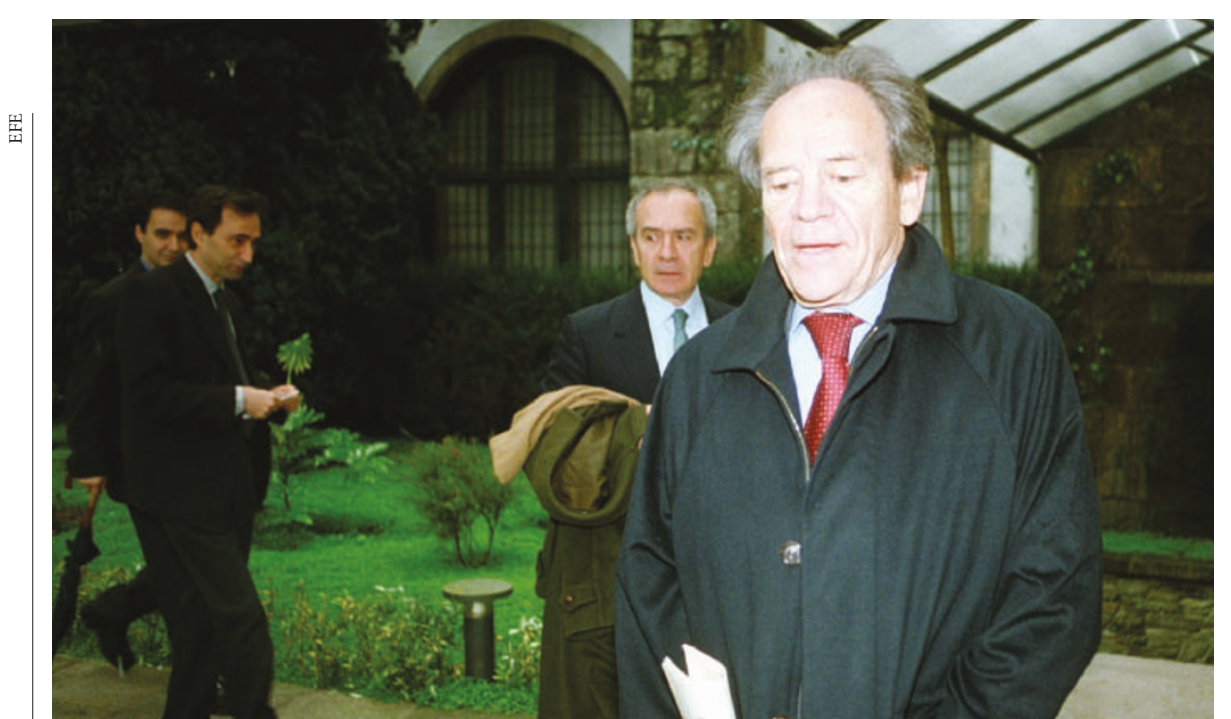

Torsten Wiesel: the Nobel laureate was 'too critical' of the US president to get a place on a scientific panel.

\title{
Bush accused of trying to foist favourites on health agency
}

Emma Marris, Washington

The former head of a US health-research agency has accused the Bush administration of rejecting most of his nominations for his centre's advisory committee — including a Nobel laureate — on political grounds.

Gerald Keusch was director of the Fogarty International Center, the branch of the National Institutes of Health that supports projects in developing countries, until last December. In a report released on 8 July by the Union of Concerned Scientists (UCS), he charges that the process for appointing members to the centre's advisory board was subject to excessive interference. The board is involved in, among other things, approving Fogarty grant applications and advising on the focus of the centre's research.

Out of 26 people proposed by Keusch for board membership during the Bush years, 19 were rejected by the office of Tommy Thompson, the secretary for the Department of Health and Human Services, Keusch says. Along with letters rejecting his candidates, he received resumés for other people that Keusch described in an interview as "lightweights" with "no scientific credibility". He adds that he felt under subtle pressure to nominate them for membership of the board. "I was never told to take any of them," he says, "but the hint was clear."

Keusch's first round of nominees to Thompson, submitted in 2001, included Torsten Wiesel, who won the 1981 Nobel Prize in Medicine for his work on visual processing in the brain. When Wiesel's name was rejected, Keusch climbed the bureaucratic ladder to find out why. Eventually, an official in Thompson's office told him that Wiesel had "signed too many full-page letters in The New York Times critical of President Bush", according to the UCS report. Keusch says that other candidates were rejected because they were associated with reproductive health or abortion rights. Last December, Keusch resigned and took a position as associate dean for global health at the Boston University Medical Campus. "I felt that I had ceased to be effective," he says.

Bill Pierce, a spokesman for the health department, points out that under the law the health secretary appoints the board. The secretary takes recommendations from other sources as well as the director of the Fogarty, Pierce says, adding that not only is scientific expertise considered, but also the mix of gender, race, geography and political opinion. "We want diversity of thinking," Pierce says.

The 34-page UCS report documented several instances of what it described as political meddling in science by the Bush administration. The report follows a similar publication that was released in February with a statement signed by a slew of scientific luminaries (see Nature428, 250-251;2004).

The latest report includes allegations that the Department of the Interior and other federal agencies suppressed the results of research on the environmental impact of a controversial mining practice called mountaintop-removal strip mining. It also says that potential appointees for several bodies were asked whether they liked US President Bush or had voted for him.

Pierce counters that the UCS itself is politically biased, noting that several of its prominent members, including chairman Kurt Gottfried, a physicist at Cornell University in New York state, have contributed money to Democrat causes and candidates. "To have an opinion is fine," he says, "but to pass yourself off as independent when you have an agenda is not. They are the ones who are politicizing science.”

\section{Indian scientists welcome broad increase in funding}

K. S. Jayaraman, New Delhi

Science spending is to get a major boost under a budget laid out on 8 July by India's new Congress-led government.

Total expenditure on research and development will increase by almost a quarter to Rs152 billion (US\$3.3 billion) under the budget for the financial year which began in April.

"There will be a $15 \%$ hike in funding for all our major projects - and that isn't bad," says Valangiman Ramamurthi, secretary of the Department of Science and Technology.

Indian scientists are delighted with the budget. "I am very pleased," says Raghunath Mashelkar, head of the Council of Scientific and Industrial Research, the largest science agency in India.

The increase is widely distributed across different spheres. Funding for fusion research at the Department of Atomic Energy will double last year's budget to Rs700 million, for example, and funding for multidisciplinary research projects at the science department will grow by Rs 400 million to Rs 2.4 billion

The budget allocates almost Rs 5 billion - one fifth of the entire space budget to the development of a new rocket, the Geosynchronous Satellite Launch Vehicle Mk-III, giving it the largest funding of any single science or technology project in the country. Gopalan Madhavan Nair, the space secretary, says the rocket will be able to launch satellites weighing up to 4 tonnes and will fly by 2007 .

A $21 \%$ increase in support for space research will also allow scientists to begin work on a Rs3.5-billion lunar orbiter mission planned for 2008 and on a recoverable satellite that could be a forerunner for a manned space mission.

The national budget - which takes advantage of strong economic growth to boost spending, despite India's growing budget deficit - includes billions of dollars for rural development. Some of the science and technology money will be channelled towards this. There will be more support for agricultural biotechnology, for example, and for technology to clean water supplies. This will include funding for the country's first commercial-scale desalination plant, in Chennai, which will be followed by a number of others.

For more news and analysis go to news@nature.com www.nature.com/news 